\title{
THE ESSENCE AND SIGNIFICANCE OF LEGALITY IN CONDITIONS OF LEGAL UKRAINIAN STATE FORMING
}

The article is devoted to clarifying the nature and value of law as an integral component of the legal state.

Comprehensively analyzes the state of the rule of law in the state, which is far from optimal and, therefore, requires the adoption of measures for its improvement.

This concept of legality, the characteristic features and investigate its legal guarantees. In particular, the conclusion that the essence of legality consists in the precise and strict observance and implementation of laws and subordinate normative legal acts of state authorities, local self-government, their officials, authorized persons and citizens. Despite the large number of interpretations of such a multifaceted the studied phenomenon, all of them in combination to reflect the essence and content of law.

To the rule of law is characterized by such main features: universality - that is, provisions of laws regulate social relations irrespective of time and place of their occurrence; universal validity - in this trait reflects the higher legal force of law as the regulations of the law binding on all subjects of law regardless of property status, belonging to public authority; validity - provisions of laws are objective, they actually send public relations profitable for the companies direction, when reaching the balance of interests of person and state; the presence of government entities ensure adherence to the rule of law.

Key words: legitimacy, the rule of law, security, protection, law enforcement agency, legal state, the rule of law.

УДК 340.115.7

Шамрук Н. Б.,
кандидат юридичних наук, викладач кафедри адміністративного,
цивільного та господарського права та процесу,
Академія Державної пенітенціарної служби, м.Чернігів

\section{СУТНІСТЬ ПОНЯТТЯ «НАСИЛЬСТВО В СІМ'Ї» ЯК ПРАВОВОЇ КАТЕГОРЇ̈}

Стаття присвячена дослідженню поняття «насильство в сім'ї» як правової категоріі. Проаналізовано різносторонні тлумачення понять «насильство», «примус», «сила», «насильство в сім'ї», «гендерне насильство» та зроблено спробу доповнення иієї правової категорії переліком суб 'єктів сімейних стосунків через призму сімейного насильства.

Ключові слова: насильство, сила, примус, сім'я, насильство в сім'ї, жертва, подружжя, батьки, илюб. 
Постановка проблеми. Реалізація особистих прав людини, гарантування права на життя і здоров'я, на вільний особистий розвиток $є$ одним із головних завдань правової соціальної держави, якою проголошена Україна. Забезпечення цих прав безпосередньо пов' язане з протидією насильницьким вчинкам i, зокрема, насильству в сім’ $\dddot{1}$.

Ученими пострадянського періоду тривалий час питання насильства в сім’ї ототожнювались лише 3 типом дрібної побутової злочинності. Лише останніми роками з'являються праці кращих наукових шкіл України, які розкривають проблеми адміністративного права і кримінології, що допомагають викласти організаційно-правові основи діяльності держави і громадянського суспільства щодо протидії насильству в сім’ї.

Тому комплексне розкриття проблематики діяльності щодо подолання явища насильства в сім’ї буде неповним без аналізу цієї категорії з позицій мови, етимології, дослідження, пов’язаного 3 цим поняттям. Це у сукупності дозволяє краще усвідомити сутність цього явища, виробити обгрунтовані шляхи його подолання.

Огляд останніх досліджень і публікацій. Проблематику сутності поняття «насильство в сім'ї» досліджували у своїх роботах учені-правники: Гусейнова А. А., Еквіно Г. Г., Ковальова О. В., Лисюк Ю. В., Ситарова В. А., Симонова В. І., Ушакова Д. М., Шамрук Н. Б. та ін.

Метою наукової статті $є$ юридичний аналіз сутності поняття «насильство в сім'̈і» та особливості законодавчого тлумачення суміжних 3 ним правових категорій.

Виклад основного матеріалу. Насильство - це форма примусу з боку однієї групи людей (однієї людини) стосовно іншої групи (окремої людини) з метою надбання або збереження певних вигід і привілеїв, завоювання політичного, економічного й будь-якого іншого панування [1, с. 135].

Прихильники насильства вважають, що життя в природі будується на насильстві, сильний придушує слабкого, тим самим забезпечуючи можливість для виживання свого виду. Тому насильство є загальним принципом існування. Цей принцип переноситься й на людину, суспільство. Їх аргументація наступна: 
якщо $є$ насильство в природі, то чому б йому не бути й у суспільстві, у взаємодії людини й природи?

Термін «насильство» досліджується, як правило, в широкому і вузькому розуміннях. Таким чином, виділяють насильство як категорію соціології (широку) і як правову категорію (вузьку).

У широкому сенсі під насильством розуміється будь-яка шкода (фізична, моральна, психологічна, ідеологічна та ін.), що заподіюється людині, або будь-які форми примусу стосовно інших індивідів і соціальних груп. В основі насильства лежить прагнення людей до панування й домінування над іншими людьми, а також боротьба за життєві ресурси, в тому числі й за владу. Наслідками насильства можуть бути фізичні й психічні травми (побої, каліцтва, смерть, біль, страх, горе, приниження гідності, стреси та ін.).

Сучасні дослідження показують, що насильство в тих або інших формах вчиняють, як правило, люди духовно слабкі. Примушуючи інших, придушуючи їх фізично й морально, вони ніби стверджуються у своїй перевазі, у своїй зверхності. Психологи пишуть про «комплекс влади, сили» (класичний психоаналіз, неофрейдизм та ін.), кар'єризм, прагненні бути нагорі, у домінуючій позиції - все це й дає ілюзія, що компенсує приховані слабкості, тому виграш у перевазі ніколи не буває повним, а в кінцевому підсумку нерідко обертається програшем [1, с. 135-136].

За твердженням Ситарова В. А., в сучасному житті насильство трапляється всюди.

По-перше, довгий час у свідомість людей впроваджувалася ідея, що мир і війна - діалектична пара понять, що випливають одне з іншого. Тисячі війн, що пройшли на планеті, переконували людей у їхній неминучості, більше того, стали сприйматися ними як щось природне, що дозволяє стверджуватися одним за рахунок інших.

По-друге, в сучасному світі все ще існує расова й національна ворожнеча, у результаті яких одні люди, а іноді й цілі народи привласнюють собі право розпоряджатися іншими, вирішувати їх політичні, економічні, ідеологічні й моральні питання.

По-третє, сьогодні існує насильство й у своєму неприкритому вигляді, не «облагороджене» політичними, ідейними й іншими мотивами, тобто злочинне насильство. 
По-четверте, примус у тій або іншій формі присутній у найрізноманітніших сферах нашого життя й діяльності: насильство над природою, невміння й небажання берегти іiі багатства, насильство над самим собою, своїм здоров'ям, жорстоке поводження 3 тваринами, не кажучи вже про факти придушення, приниження особистості, які мають місце в місцях відбування покарання, в армії та ін.

По-п'яте, насильство може бути не в прямій, а в прихованій формі (міжособистісні конфлікти, прагнення до ствердження особистих амбіцій, бажання самоствердитися будь-яким шляхом тощо) [1, с. 135-136].

У соціальних, сімейних стосунках насильство виявляється через пригнічення дитини батьками, які керують ії повсякденною поведінкою та розвитком, безальтернативне примушування одного члена сім'ї іншим до певної поведінки чи утримання від певних дій, застосування різних інструментів для цього: фізичне побиття, психічне приниження, обмеження економічної свободи тощо.

Філософська думка наводить антонім категорії насильства: ненасильство - це ідеологічний, етичний і життєвий принцип, в основі якого лежить визнання цінності всього живого, людину і його життя, заперечення примусу як способу взаємодії людини зі світом, природою, іншими людьми, спосіб вирішення політичних, моральних, економічних і міжособистісних проблем і конфліктів, ствердження й посилення здатності всього живого до позитивного самопрояву [1, с. 138].

Насильство, як правило, зіставляється 3 цілеспрямованим обмеженням свободи вибору поведінки, підпорядкуванням, порушенням прав і завданням збитків людям та їх спільнотам, що приводить до визначення його через поняття «примус». Так, Гусейнов А. А. описує насильство як зовнішній, силовий вплив на людину або групу людей, «примус, збиток життя й власності, які здійснюються всупереч волі тих, проти кого вони спрямовані». Метою насильства $є$ підпорядкування особи свідомості того, хто здійснює такий вплив, а тому насильство визначається ним як узурпація волі, один зі способів, що забезпечують панування, владу людини над людиною. На думку цього вченого, механізм насильства полягає у тому, що людей примушують до певних 
вчинків або до утримання від певних учинків за допомогою прямого фізичного впливу. Насильство - це суспільні відносини, у ході якого одні індивіди (групи людей) за допомогою зовнішнього примусу, що являє собою загрозу життю, підкоряють собі інших, їх здатності, продуктивні чинності, власність [2, с. 36].

Як видно з вищевикладеного, між категоріями «насильство» й «примус» є прямий взаємозв'язок. Саме через слова «незаконне», «сила» й «примус» розкривається у словниках слово «насильство».

Примус - дія за типом примусити-примушувати; насильство, насильницька міра [3]; насильство над волею індивіда або соціальної групи шляхом застосування санкцій [4].

Примус мас такі синоніми, які підтверджують його зв'язок 3 категоріями сила і насильство: силування, змушування, примушування, неволення, приневолення [5].

Так, Всесвітня організація охорони здоров'я визначає насильство як навмисне застосування фізичної сили або влади, що реалізоване у вигляді погрози, спрямоване проти себе, проти іншої особи, групи осіб або громади, результатом якого є (або $є$ високий ступінь імовірності цього) тілесні ушкодження, смерть, психологічна травма, відхилення в розвитку або різні несприятливі наслідки [6, с. 17].

Варто погодитися 3 точкою зору про те, що «насильство» $\epsilon$ лише частиною, одним 3 видів примусу, що за своїм змістом охоплює цю категорію. Примус може бути заснований через майнову, організаційну та інші сторони життєдіяльності, насильство ж завжди впливає безпосередньо на особу через іiі біологічну підструктуру [7, с. 3].

Енциклопедичний словник визначає сім'ю як засновану на шлюбі або кревному спорідненні малу групу, члени якої пов'язані спільністю побуту, взаємною допомогою, моральною й правовою відповідальністю [8]. У цьому визначенні для категорії «сім'я» вживаються й інші ознаки, крім спільного проживання: ведення спільного господарства, надання у зв'язку з цим допомоги та відповідальність за вчинки один одного.

Ця теза підтверджується положеннями статті 3 Сімейного кодексу України [9], відповідно до якої сім'ю складають особи, які спільно проживають, пов'язані спільним побутом, мають вза- 
ємні права та обов'язки. Подружжя вважається сім'єю і тоді, коли дружина та чоловік у зв'язку з навчанням, роботою, лікуванням, необхідністю догляду за батьками, дітьми та з інших поважних причин не проживають спільно.

Податковий кодекс України виходить з категорій членів сім’ї першого та другого ступенів споріднення. Згідно 3 пунктом 14.1.263 Податкового кодексу України [10] членами сім'ї фізичної особи першого ступеня споріднення вважаються їі батьки, чоловік або дружина, діти, у тому числі усиновлені. Інші члени сім'ї фізичної особи вважаються такими, що мають другий ступінь споріднення.

Сімейне насильство, як і його синонім сімейно-побутове насильство, зачіпає людей соціально-економічного оточення, воно може трапитися 3 подружжям, особами, які спільно проживають або становлять близьке коло спілкування. Не $є$ обов'язковою ознакою в останньому випадку шлюб чи сімейні стосунки, спільне проживання, навіть тимчасові спільно побутові стосунки (наприклад, періодичне проведення вечірок знайомими чи сусідами може слугувати ознакою кваліфікації агресивних дій як насильства в сім’ї (англ. Domestic violence)).

Поняття насильства в сім'ї, виходячи з узагальнення досліджених категорій, доцільно аналізувати на основі нормативних положень та змісту наукового аналізу, проведеного вченими.

Так, у публікаціях вітчизняних та зарубіжних дослідників висловлювались критичні зауваження щодо недостатнього врахування відмінності жертв насильства в сім’ї. Зокрема, Ковальова О. В., Лисюк Ю. В., Еквіно Г. Г. пропонували чітко визначити членів сім’ї, які можуть бути жертвами насильства у сім'ї. До них, зокрема, доцільно відносити:

- подружжя та партнерів, які проживають разом або за взаємною згодою мають тривалі (більше 1 року) інтимні чи інші значущі стосунки; колишне подружжя та колишніх партнерів; батьки (мати, батько) та дитина (діти); усиновителі (усиновителя) та усиновлені; дід (бабуся) й онук (онука); вітчим (мачуха) й пасинок (падчірка); брати та сестри; фактичні вихователі і вихованці; тітка (дядько) та племінник (племінниця); інші родичі; домашні робітниці та члени їх сімей $[11$, с. 28$]$; 
- особи, що перебувають або перебували в родинних стосунках, перебувають або перебували в шлюбі один з одним, проживають або проживали разом, мають спільну дитину незалежно від того, чи були вони колись одружені, зустрічалися чи зустрічаються.

Законодавець реалізував це зауваження шляхом внесення змін у базовий закон від 25.09.2008 р. «Про попередження насильства у сім'ї» [12], який визначає цю категорію як будь-які умисні дії фізичного, сексуального, психологічного чи економічного спрямування одного члена сім'ї стосовно іншого члена сім’ї, якщо ці дії порушують конституційні права і свободи члена сім’ї як людини та громадянина і наносять йому моральну шкоду, шкоду його фізичному чи психічному здоров'ю.

Доцільно зазначити, що категорія «члени сім'ї», попри іï нормативне закріплення, потребує певних уточнень. Так, у ході вивчення та узагальнення нормативних джерел, цих емпіричних досліджень, було виявлено такі ії недоліки:

1) недостатньо враховано вчинення насильства в сім'ї шляхом бездіяльності та погрози;

2) уточнююча категорія «члени сім'“і» змістовно відрізняється від аналогічного поняття, прийнятого у сімейному і інших галузях законодавства;

3) підкатегорія «моральна шкода, шкода фізичному чи психічному здоров'ю» не збігається 3 теорією і практикою відшкодування шкоди у різних галузях захисту прав людини;

4) залишено поза увагою пропозицію Ковальової О. В. щодо урахування тривалих інтимних чи інших значущих стосунків агресора і жертви насильства, адже за нинішньою редакцією закону це буде розглядатися лише у разі їх спільного проживання;

5) не враховано факт насильства, заподіяного іншим людям, які не проживають спільно, але мають постійні спільні стосунки (зустрічі та спілкування сусідів, родичів, проживання окремо, але по сусідству батьків чи інших родичів);

6) хатніх працівників, що проживають разом або окремо, але тривалий час перебувають у помешканні сім’ї, в якій вчинюється насильство;

7) не враховані нові форми влаштування дітей-сиріт і дітей, позбавлених батьківського піклування; 
8) категорія «проживають однією сім'єю» наведена чи не вперше у вітчизняному законодавстві і iї тлумачення неоднозначне.

Насильство в сім'ї - будь-яка навмисна дія одного члена сім' $і$ проти іншого, якщо ця дія порушує конституційні права й свободи члена сім'ї як громадянина, заподіює йому фізичний біль i завдає шкоди або містить погрозу фізичному або особистісному розвитку неповнолітнього члена сім’і.

Визнаючи першість правової категорії «насильство у сім'ї», все ж вважаємо доречним як терміни синонімічного значення у наукових та прикладних працях застосовувати категорії «домашнє насильство» (дослівний переклад англ. domestic violence), «гендерне насильство» (у більшості випадків насильства у сім'ї, що мають стосунки між статями), «сімейне насильство».

Висновки. Таким чином, детально розібравши сутність досліджуваної нами правової категорії, ми дійшли висновку, що насильство у сім’і є будь-якими умисними діями (бездіяльністю), а так само погрозою вчинення фізичного, сексуального, психологічного чи економічного насильства одним учасником сімейних стосунків щодо іншого, якщо ці дії порушують права і свободи члена сім’ї і завдають йому матеріальну чи моральну шкоду.

Наведене визначення обов'язково доповнювати переліком учасників сімейних відносин у розумінні насильства в сім’ї:

- особи, які перебувають у шлюбі або протягом тривалого періоду проживають разом;

- особи, які проживають окремо, але підтримують значущі родинні, особистісні стосунки, а так само господарські працівники, з якими підтримуються особистісні стосунки;

- їхні діти та особи, які виховуються ними за різними формами влаштування дітей-сиріт і дітей, позбавлених батьківського піклування;

- родичі прямої або непрямої лінії споріднення, які проживають разом.

\section{Список використаних джерел}

1. Ситаров В. А. Насилие и ненасилие. Знание. Понимание. Умение. 2005. № 1. С. 135-139.

2. Гусейнов А. А. Понятие насилия и ненасилия. Вопросы философии. 1994. № 6. С. 36. 
3. Толковый словарь Ушакова. http://dic.academic.ru/dic.nsf/ushakov/974530.

4. Энциклопедия социологии. URL: http://dic.academic.ru/dic.nsf/socio/3053.

5. Словопедія. Словник синонімів. URL: http://slovopedia.org.ua/41/53407/271668.html $>$ ПРИМУС $</ a>$.

6. Токарчук Р. Е. Насилие как составообразующий признак хищений: вопросы уголовной ответственности: дис. ... канд. юрид. наук: 12.00.08 / Омский гос. ун-т. Омск, 2008. 178 с.

7. Симонов В. И. Уголовно-правовая характеристика физического насилия: автореф. дис. ... канд. юрид. наук. Свердловск, 1972. 17с.

8. Энциклопедический словарь. URL: http://dic.academic.ru/dic.nsf/es/51949.

9. Сімейний кодекс України від 10 січня 2002 року № 2947-III. Відомості Верховної Ради Украӥни. 2002. № 21-22. Ст. 135.

10. Податковий кодекс України від 02.12.2010 № 2755-VI. Oфiиiŭний вісник Украӥни. 2010. № 92. Т. 1. Ст. 3248.

11. Ковальова О. В. Діяльність служби дільничних інспекторів міліції щодо попередження насильства в сім’ї: дис... канд. юрид. наук: 12.00.07 / Харківський національний університет внутрішніх справ. Харків, 2008. 238 с.

12. Про попередження насильства в сім'ї: Закон України від 15 грудня 2001 року за № 2789-III. Відомості Верховної Ради Украӥни. 2002. № 10. Ст. 70.

\section{СУТЬ ПОНЯТИЯ «НАСИЛИЕ В СЕМЬЕ» КАК ПРАВОВОЙ КАТЕГОРИИ}

Статья посвящена исследованию понятия «насилие в семье» как правовой категории. В данной статье проанализированы разносторонние толкования понятий «насилие», «принуждение», «сила», «насилие в семье», «гендерное насилие» и сделана попытка дополнения данной правовой категории перечнем субъектов семейных отношений сквозь призму семейного насилия.

Ключевые слова: насилие, сила, принуждение, насилие в семье, жертва, супруги, родители, брак.

Shamruk N. B.

\section{THE ESSENCE OF THE CONCEPT «VIOLENCE IN} FAMILY» AS LEGAL CATEGORY

Human rights exercising, the guaranteeing the right to life and health care, to free personal development are the major tasks of the law-based social state defined 
by the Constitution of Ukraine. Guaranteeing these rights is closely connected with counteraction against violent actions and domestic violence in particular.

Scholars of the post Soviet period identified domestic violence with minor everyday crimes. The works of the best scientific schools of Ukraine have been published lately. They show the issues of the administrative law and criminology and help the define organizational and legal fundamentals of the activities in the state and public in the society regarding domestic counteraction against domestic violence.

That's why exposing the subject of counteraction against domestic violence is incomplete without the analysis of this category with the attitude taking into account language, etymology, the investigation dealing with it. The combination of all these investigations makes it possible to realize better the essence of this phenomena, to work out well-founded ways of its overcoming.

"Domestic violence» as well as its synonim «domestic everyday violence» concerns people from the social and economical environment, it may happen to any couple, to people who live together or are in close relationship. Marriage, family relations, joint residence, even temporary common everyday relations (for example, periodic giving parties by neighbours, friends may be qualified as acts of aggression and as domestic violence) are not a compulsory (indication) National and foreign publications give critical remarks regarding incomplete considering the probable victims of the domestic violence. In particular Kovaliova $O$. $V$., Lysiuk $V$., EKvino G.G. suggested to make a distinct list of the family members who may become victims of domestic violence.

Key words: violence, force coercion, violence in the family, the victim, spouses, parents, marriage.

Катеринчук І. П., доктор юридичних наук, ректор Одеського державного університету внутрішніх справ

\section{ВИЩИЙ НАВЧАЛЬНИЙ ЗАКЛАД ЯК СУБ'СКТ ПРОФІЛАКТИКИ ПРАВОПОРУШЕНЬ: ДОСВІД ОДУВС 3 КАДРОВОГО ТА ЗАКОНОДАВЧОГО ЗАБЕЗПЕЧЕННЯ ПРАКТИКИ}

У статті показані результати наукового дослідження діяльності вищзого навчального закладу як феномена $і$ суб'єкта профілактики правопорушень. Автором представлений досвід Одеського державного університету внутрішніх справ з особливостей роботи навчального закладу з кадрового та законодавчого забезпечення профілактичної практичної діяльності Начіональної поліціiі. Представлено головні напрямки роботи університету з якісної підготовки правоохоронців у сучасних умовах як профілактичного підгрунтя ефективного забезпечення правоохоронної діяльності. Визначено проблеми функиіонування 